\section{Between the}

\section{disciplinary past} and the practical past: figurations of the historian in the crisis of
the humanities

Entre o passado disciplinar e os passados práticos: figurações do historiador na crise das humanidades

\section{Rodrigo Turin[*]}

[*] Department of History, Universidade Federal do Estado do Rio de Janeiro (Unirio) - Rio de Janeiro (RJ) — Brasil. E-mail: rodrigoturin@gmail.com ORCID: https://orcid.org/0000-0003-2385-9961

\section{Article}

Resumo: O objetivo deste artigo é refletir sobre a historicidade das formas disciplinares, investigando os critérios que balizaram as condições de emergência da disciplina histórica, assim como seus atuais (possíveis) esgotamento e crise. Em uma conjuntura em que a cultura histórica se difunde por meio de diferentes mídias, nas quais se valoriza muito mais a fragmentação e a pluralização, via memória, do que uma homogeneização, via história disciplinar, torna-se importante investigar os modos pelos quais os historiadores hoje redefinem sua identidade, enfrentando esse encontro entre a tradição disciplinar e as demandas contemporâneas.

Palavras-chave: humanidades; historiador; disciplina.

Abstract: The purpose of this article is to investigate the historicity of disciplinary forms, investigating the criteria which guide the conditions for the emergence of the discipline of history, as well as its current (possible) exhaustion and crisis. In a context in which historical culture is disseminated by different media, and in which the fragmentation and plurality of identities - via memory are far more highly valued than homogeneity — by means of the discipline of history - it is important to investigate how historians of the present redefine their identity and approach this juncture between the disciplinary tradition and contemporary demands.

Keywords: humanities; historian; discipline. 
"Every epoch should always try to rip tradition from the sphere of conformism which prepares to dominate it". - Walter Benjamin

$\mathrm{W}$ e are going currently through an intense discussion about the working conditions of historians and the place of the discipline of history and of the humanities in society. ${ }^{1}$ An unmistakable sign of this are projects, in various countries, for the remodeling of the teaching system, aimed at the reduction of the number of hours of the humanities, or even their extinction, in the name of a pedagogy concerned with the abilities required by a market going through an accelerated transformation. Similarly, a sensitive reduction in investments in the humanities in the university system can be perceived, under the increasingly common justification of their "uselessness" in relation to more practical sciences (Ordine, 2016; Nussbaum, 2015). Not by chance, a possible "end of history" is considered today as something concrete, not in the sense given to it by Fukuyama at the beginning of the 1990s, but in relation to the disciplinary sense, and with this also a consequent "end of historians" (Léon; Martin, 2008). It is the institutional face of the humanities and their social role, as has existed since the nineteenth century, which now seems to be in danger of extinction.

Rather than reacting by brandishing the supposed virtues inherent to historical knowledge, based on determined common places inherited from tradition, it is perhaps the moment for the discipline to also carry out its own self-analysis, seeking to think with - and in opposition to - the tradition which constituted it, as a condition of the preparation of a new disciplinary imagination. The aim of this text is to test some paths for this reflection, trying at the same time to draw a broad temporal arc which will allow the visualization of both the emergency conditions and the crisis in the disciplinary form of history, in the broader field of the humanities, as well as the tensions, clashes, and conflicts which now surround the reconfiguration of the place of the discipline and its identity. The central argument I have sought to develop in the three movements which compose this paper is aimed at identifying how the exhaustion of original conditions of the emergence of the discipline ended up making it face a dual pressure, both external and internal. Externally, in relation to the new configurations between state-societyuniversity in the accelerated and globalized world of late capitalism, occurring in specific policies for evaluating and devaluing historiographic production and of the humanities

${ }^{1}$ This text is the fruit of reflections carried out in a cycle of meetings "(In)disciplined history", held in UFRGS. I would like to thank all the participants for their valuable criticisms and suggestions, as well as my colleagues Pedro Caldas, Mateus Henrique de Faria Pereira, Aline Magalhães, Martin Wiklund, Thiago Nicodemo, Géssica Gaio, and Arthur Assis for the critical reading of previous versions of the paper. 
in general; and internally, to the extent that these new configurations also represent, in another manner, the emptying of the bases and frontiers which shaped disciplinary identity, also impacting both on a theoretical deficit of self-legitimation and the current dispersal, in relation to the understanding of their pedagogical purposes, as I will analyze at the end of the article. In other words, history as a discipline, as well as the humanities, is subject to a dual pressure for reforms, whether from outside, moved by new public administration policies and their languages, such as "excellence", "productivity", "impact;" or from within, based on the work of the reorganization of aims and disciplinary frontiers, advancing new languages of legitimation theories, and also new purposes and abilities in their formation. Two forms of action and temporality are in play: disciplinary autonomy and the heteronomy of the market-state.

To start this reflection, however, I would like to begin by turning to two recent facts and reports, in order to introduce the problem to be discussed.

The first report, published in a blog about education in a mainstream newspaper, is entitled "Educate for happiness". Its aim was to guide parents, offering them certain guidelines to plan the education of their children. For this, the author establishes a persuasive analogy for her implicit readers, which is revealing for the argument of interest here:

It is known that the majority of companies have excellent strategies to develop their business and grow. However, only some manage to really implement the chosen strategies. The difference is precisely in the capacity to focus and one the implementation of a good plan of action.

It is also like this with our children (Estadão, 2015).

The second report, dedicated to the "professions of the future", concentrates on showing new opportunities which can be explored by historians, more specifically by the category of "corporate historians", in the preparation of "memory solution" archives and strategies for companies. This activity demands, on the one hand, the (supposed) technical abilities of the historian with archives and, on the other, a degree of astuteness to understand the demands of companies and their insertion in the market, in relation to which they need to offer the above mentioned "memory solutions". It also contextualizes these demands within an actual intensification of academic studies about memory. As one of the interviewees states, a trained historian and with a postgraduate degree in administration:

The search for the memory of post-modern society has been countering the acceleration of time. I think that memory serves a little to nurture individual and collective identity and to attribute meanings to reality. Thus, the role of the historian is to give this a use. It is not worth making memories for memory. You have to give this a use (Estadão, 2015). 
What I would like to highlight, based on these reports, is how a similar language shapes these two spheres, school education and the historiographic trade, which reveals a similar

grammar based on which various experiences are now conceived and measured, including (and above all) education and history. Educating, in this perspective, is being an entrepreneur, incorporating the same entrepreneurial language, based on effectiveness, on optimization, and an instrumental reasoning aimed at feeding itself and expanding (Dardot; Laval, 2016). Similarly, the relationship with the past, in the perspective of memory, is inscribed as a good to be optimized, capitalized, allowing both greater efficiency in the resolution of market challenges, and also as a good (and a service) to be sold in function of plural (and occasional) identity demands, as compensation for an increasingly accelerated world. The actual theoretical principle of a continual rewriting of history is transformed here into an opportunity, into a principle of capitalization. After all, as the report states: "History continues to be told every day. Well administrated, this core exists in the 'forever' and has a lot of value". The Thucydidean topos of the writing of history as a "a valuable possession for all time" finds a new fortune here.

\section{First movement: historical experience, acceleration, and new concepts of movement}

In the justifications prepared for the reform of second level education in Brazil, in an analogous manner, the vocabulary in which this process has been expressed is still revealing: the student idealized in these projects needs to "acquire basic skills" in order to develop the "flexibility" necessary for a market in continual and accelerated transformation. It is with these principles, following the PISA model, (Programme for International Student Assessment), using the OECD database, which legitimates dominion in the broad areas of mathematics and language, conceived as the most appropriate "instruments" for this new form of purpose without purpose, flexibility. Instead of notions such as "formation" and "development", on which pedagogical projects in classical modernity were based, and which indicate a determined conception of subjectivity, as well as temporality, we can see the sedimentation of new categories which reveal distinct forms of subjectivities and historicity. The already mentioned notion of "flexibility", for example, which is at the center of this process, is characterized by a spatial-temporal opening without any telos. It is about the capacity for reaction (more than action) to a state of continuous and hyper-accelerated movement, but which is not directed at any specific place. Not by chance, this concept has become ever more current in society from the 1980s onwards, first with economic and work organization vocabulary, replacing the rigidity of the Fordist model, and afterwards expanding to other 
spheres, such as the cultural. "Flexible accumulation", as David Harvey calls it, was part of a process of rapid changes in the patterns of development, producing a diversification in the industrial sector, creating, for example, the so-called "services sector", as well as implying a "compression of space-time", when "the temporal horizons of private and public decision making are narrowed", (Harvey, 1997, p. 140). Becoming common vocabulary to express different experiences in a same temporal form, the concept of "flexibility" carries in itself a sensitive transformation in the conception of history, emptying the various teleological dimensions, loaded with the future, which have qualified their procedural dimension since classical modernity.

The modern metaphor of the "train of history" is emptied here of meaning, since there is no starting point, let alone an arrival point. There is only movement, but a movement whose instants no longer have any differential quality before the "before" and "after". As the concept of "progress" has been established since the end of the eighteenth century as an indicator capable of being used in various experiences of modernity, the concept of flexibility now similarly seems to have assumed this function without a determined Subject, content for this reason, it can be extended to various experiences: from state administration to pedagogical projects, becoming a type of universal virtue to be sought after and acquired. The implosion of metanarratives, much vaunted since Lyotard"s classical work, finds its equivalent in the implosion of the narrative forms of daily temporality, and this is enrooted in concrete social experiences. The emergence of new contents of experience thus questions not only the sedimented forms of the great historical narrative, but equally the forms of narrative of the self, traditionally expressed in notions such as "liberation", "emancipation", and "project" (Elliot; Urry, 2010). While the concepts of movement of classical modernity are essentially characterized in function of determined historic telos, these new concepts of movement which appear to emerge in contemporary society configure a new form of temporality, marked by social hyper-acceleration and by the absence of a telos which organizes it as a narrative order.

It is not possible to think about the creation of modern teaching institutions, in the school-university system, without taking into consideration the historical aims which have guided them. In visiting the founding texts of these institutions, such as those of W. Humboldt, we can see how the concepts of "autonomy" and "liberty" are prepared as necessary conditions for the "formation" of a full individual, who Goethe calls the "universal-historical individual" (Humboldt, 2003; Dilthey, 2010). No matter that there are tensions between the demands of a still incipient specialized labor market and the strictly pedagogical demands, these are always maintained as the ultimate substrata of the legitimation of the teaching system, to the extent that they promote the work of social and political "synchronization", making the individual part of his time, and with this a determined sense of historical orientation. Not by chance, as Aleida Assmmann has 
highlighted, the concept of Bildung (education) emerged when in the modern epoch the concept of "progress" was institutionalized. Bildung is, thus, essentially linked to history; "it is the synonym of the education of man in time, or of the evolution of humanity in history" (Assmann, 1994, p. 25). Even in its first crisis, at the beginning of the twentieth century, in light of the spiral of specialization, this connection can be remade, as in the case of Weber, and Jaspers, amongst others, projecting an ideal regulator for the university disciplines (Weber, 2015; Jaspers, 1989). It is this equation between teaching and education, sedimented on a determined historical experience, which appears to be emptied of content, and replaced by the principles of "skills", "excellence", and "flexibility", more suited to a world in accelerated transformation.

The same can be considered based on examples offered by the sociologist Hartmut Rosa (Rosa, 2010). While in the nineteenth century and in a good part of the twentieth, professional trajectories were structured in singular activities, in which individuals sought to follow "careers", since the 1970s and 1980s, the data increasingly shows a process of diversification of professions which an individual exercises during their life. Due to the acceleration of capital flows, the mobility and segmentation of production centers, and the acceleration of technological innovations, amongst other factors, individuals have come to live the experience of always starting again, jobs become temporary positions, experiencing uncertain situations, without there being the old structural conditions for investment in a career as a "life project". In addition, similar data points to a change in the perception about temporal ruptures. While until the middle of the twentieth century this perception of temporal rupture occurred through generations (grandparents, parents, children), the perception of rupture is increasingly inserted in an intragenerational dimension. Within a generation, in a short interval of 20 or 30 years, the sensation of distancing from past experiences has been produced, a large part of which were made obsolete. This can be observed in the ever more intense feeling of nostalgia, no longer for past "epochs", as in romantic sensibility, but rather recent decades: first, with the 1980s, now with the 1990s, resulting in what Ricardo Piglia called a "cheapening of the market of history", (Piglia, 2016, p. 13). This hyper-acceleration, paraphrasing the writer Aleksander Hemon, ended up producing an "ontological crisis", since the subject is forced to permanently negotiate the conditions of their individuality under perpetually different existential circumstances (Hemon, 2013, p. 23). Resulting from this is the rising incapacity of those categories of classical modernity, such as "formation" and "development", to express the temporal dimension of these new fractured social experiences. The absence of a future figured as a project and the incessant replacement of the present can be found in categories such as the "flexibility", "efficiency", and "updating" of its own semantic network (Pereira; Araujo, 2017). 
The categories still equally inform our contemporary political experience, marked by a growing de-synchronization between civil society and the state, increasingly understood as a sphere of administration, which has to react in an accelerated manner to the demands of the international financial market, emptying the actual time of representative democracy (Rosa; Scheuerman, 2009; Hassan, 2009). From this results the emptying of the mechanisms of political representation in the name of the "efficiency" of administration. A good project is perhaps the preparation of a dictionary of these new concepts of movement so that we can reconstitute the complexity of the temporal dimensions of our current semantic network, in its distinct social strata, going beyond the far too broad categorizations which contemporary historiography still provides as diagnostics.

In addition to these broad "pedagogical pressures", generated by new social configurations, another aspect which has been affecting the place of the discipline of history can be perceived in the intensification of debates about the ethical implications of historical narratives in relation to demands for identities and plural memories, as well as in relation to the traumatic events of the twentieth century. Here, the dimensions of memory, pardon, justice, and citizenship have been creating challenges to and even imposing ethical barriers on the relationship which professional historiography has traditionally had with witnesses from the past and with the preparation of its narratives, stressing the justifications of truth, objectivity, and distancing which, within the disciplinary tradition, guide and legitimate their work (Ricoeur, 2010). Although it is an error to overestimate the social effects of memory discourses about the violence and trauma of the past (it is enough to see the return and the contemporary virulence of the discourse which produced these traumas), it is obvious that they are very present in the historiographic community, inciting debates about the nature of the profession and its time policies (Lorenz; Bevernage, 2013).

In this scenario, intensified by the variety of medias available to the different social agents, historians increasingly see their authority being intensely disputed in the public arena, reducing the strong distinction between professionals and amateurs established in the nineteenth century. What remains of this distinction? What can nowadays sustain the profession of historian and their role in society in light of these new social and political experiences? Should the historian be the loyal guarantor of a historical truth or rather become a type of mediator of memories, a curator of other pasts? Should they offer the so-called "services in history" or, more exactly in "memory", adapting them to the demands of an increasingly more accelerated and flexible market? In short, to what extent do these new external socio-political demands not imply the undermining of internal and disciplinary criteria, inherited from tradition? It is in relation to these questions that the academic historiographic communities seem to be searching for a new insertion in its present. 


\section{Second movement: the temporal arc in the discipline of history}

It is well known that the discipline of history is a modern phenomenon. Before the nineteenth century, it was distributed in a series of distinct genres, involving different protocols of reading and writing, distinct erudite practices, and meeting various purposes, classified in the treaties as belonging to the epididytic genre, with nuances in the deliberative and judicial genres. The choice of writing a historic text, in this broad sense, is presented as one possibility amongst others, not implying a specific delimitation or delimitation of the person who wrote. Furthermore, the voice of the historian was assumed rather than being a historian. The delimitation was thus more in the specific genres than in the agent strictly speaking. Similarly, there was no project or institution of "historical education", in the school sense. Even with the formation of academies in the eighteenth century, this type of functioning of the machinery of genres, according to Alcir Pécora's useful phrase, was not essentially altered.

This would only actually occur with the shaping of a disciplinary logic from the nineteenth century onwards, later crystalized in the reforms that would result in the profile of the modern university. In this process, which occurred in distinct modes and at specific times in different countries, the delimitation of the authority of the text stopped being anchored on eminently rhetorical protocols to be definition by the formation of a specific agent, the historian, through the implementation of an obligatory curriculum and recognized emblems and titles. In this process, the abilities and certain epistemic virtues which qualified this subject of knowledge were defined, predominantly centered on documental critique and impartiality, as well as the genres through historians could express themselves, such as the monographic book, articles, and reviews, governed by specific protocols which translated those abilities and virtues, constituting what Anthony Grafton called the "dual narrative" (Grafton, 1998).

As Peter Weingart has highlighted, the emergence of the modern disciplines, occurring around 1800 , implied a distinct mode of producing experiences or data, which came to be generated and controlled through primarily internal protocols, and no longer occasional ones (Weingart, 2010). In other words, the judgement of the relevance of a research agency, as well as the forms of its execution, became rules for peers, institutionalizing a hierarchical chain of formation and reproduction in this relatively autonomous space. It is in this sense that Weingart defines the essence and the evolution of disciplines through self-referential communication, normally established through congresses, associations, and periodicals. Generating a spiral of specialization, while at the same time research innovation was associated with teaching, the disciplines were, at least ideally, oriented by the principle of autonomy, since the opening which characterized the research was based on the production of novelties which could not and should not be defined beforehand. It is in this sense that 
authors such as Weber and Jaspers, for example, defined science as an essentially open and infinite task, in the same form that, since Humboldt, the university was thought of as a socially constituted sphere to guarantee the scientific-pedagogical connection between autonomy and education.

Pedagogical organization and scientific innovation, pillars of the modern notion of discipline, continued to assume specificities in accordance with the areas, principally in relation to the degree of autonomy exercised in practice. In the case of History particularly, it is not possible to think of its disciplinary insertion without connecting it to the umbilical relationship it maintained with the modern Nation-State. At the same time that it offered a language through which the national experience could be thought about, the state housed it and promoted it as legitimate knowledge to compose the disciplinary spectrum. As Stefan Berger highlighted, this process of establishing a stronger distinction between professionals and amateurs, guaranteeing a scientific authority, is what allowed the historian play such a preponderant role in the phase of the formation of national identities, acting as the pedagogues of the nation (Berger, 2007, pp. 32-33). Jointly with this institutional organization of the discipline, its strong arm was invested in, which was the replication of the historiographical production in the teaching system. Even in spaces where the university, in the modern sense, was constituted later, this strong relationship between the disciplinization of history and teaching is patent. In the French case, for example, the process of disciplinization via lycées and the Ecole Normale, was closely linked to Guizot's effort to massify teaching, guaranteeing homogeneity in the education of the citizen (Rosanvalon, 1985). Although it was not possible to avoid it completely, at the very least what Fustel de Coulanges called a "historiographic civil war" should be controlled (Hartog, 2003). In the Brazilian case, in turn, this occurred even before the universities, with the joint creation of IHGB and Colégio Imperial Pedro II (Toledo, 2005). As the discourse of history became fundamental for the intelligibility of the most distinct experiences, above all of politics, the danger of its dispersal and the resulting conflicts were still a strong motivation to promote the restriction of its production, separating a professional, disciplinary, competence from the "amateur" interests and demands of the past. This discipline of history - which it should be understood did not occur in a purely mechanical manner - presented itself as knowledge essential to the political form of the Nation State, since to a large extent it was through it that sovereignty became effective in a homogenous and homogenizing narrative, carrying out what Jacques Rancière denominated a triple contract of the poetics of history: narrative, scientific, and political (Rancière, 1994). In the equilibrium between disciplinary autonomy, social demands, and political action, historians could support themselves in a position in which the belief in empirical objectivity guaranteed by the documents of the past allowed the authority and the effects of its political statements (Gengnagel; Hamann, 2015). A stability which can 
be understood as one of the elements responsible for what Koselleck called a "theoretical indigence of the discipline" (Koselleck, 2014). To the contrary of other disciplines, such as Sociology and Anthropology, which needed strong theoretical investment in order to conquer their legitimacy, History and historians were able to anchor themselves on this pedagogical link with national identity, claiming for themselves the place of empiricism and a certain reification of the past.

While there was not exactly a strong theoretical effort at legitimation, this does not mean that this process of disciplinization has not resulted in the preparation of a historiographic discourse of identity, through which the constitutive criteria of each disciplinary field have been drawn. In the same historical movement in which history became a scientific discipline, it was shaped and a genre (or subgenre) sedimented, the history of historiography, which sought to show the unity of its objects - history and historians. It was to a great extent due to the framing and the confrontation of the tradition, produced by this meta-historic discourse, that the abilities and epistemic values were drawn for the subject of knowledge, such as "objectivity" and "distancing", varying the resolutions of form and genre, according to the contexts and conflicts of each moment in the historiographic field (Turin, 2013).

However, defining what is essentially historical or historigraphical, equally implies establishing what is not. The understanding of this delimitation of disciplinary unity, thus, cannot ignore its eminently relational aspect, in other words, how it defines itself in relation to the other disciplines being constituted, such as anthropology, sociology, and even literature. From this arises the sedimentation of determined topoi which are still incorporated by professors and students in a disciplinary habitus, creating determined associations familiar to all: history with the document, identity, and the past; sociology with general laws and modern societies; anthropology with fieldwork and the study of alterities. This disciplinary constellation and its topoi have themselves a profound connection with their condition of having emerged in the nineteenth century. While history, for example, was constituted in function of national identity, temporality, and writing, anthropology, in turn, dealt with alterities, with spatiality, and with orality which, thus, correspond to the negative of modern nations, updated in a series of opposing and asymmetric pairs (Duchet, 1985).

However, as these cleavages came to be problematized and emptied of meaning, especially in the second half of the twentieth century, at the same moment that the humanities acquired greater institutional autonomy in relation to external interference, these disciplines found themselves confronted with the challenge of preparing at the same time a critique of their marks of origin and a new normative and legitimating orientation. In this process, a kaleidoscope of approaches was opened, as well as the discourse of an inter- or intradisciplinarity. Anthropological history, historical anthropology, urban anthropology, historical sociology, sociological history, subaltern studies, structural history, connected 
histories, cultural studies, are only some of these manifestations which still equally reveal the difficulties of escaping from or surpassing the problem of disciplinary difficulties in the humanities. No matter how difficult it may be, if not impossible, establishing an epistemological distinction between forms of knowledge such as history, anthropology, and sociology, to the same extent that those distinctions which shaped their emergence (such as the division of societies) have already lost legitimacy, everyone is aware of the existing and resistant feuds between these disciplines, or worse, what seems to dominate today, their mutual ignorance (Passeron, 1995). However, this entire process of criticism and selfcriticism, of the inter- or intra-disciplinarity of the humanities, principally triggered since the 1970s, has little affected their institutional delimitations. As Andrew Abbot has highlighted in relation to the social sciences in the United States, in this process there was at the same time an incredible stability of institutionalized disciplined and an extraordinary instability of their paradigms or theoretical currents. While there was a succession crisis and a strong expansion of the body of researchers at that moment, as authors such as Bourdieu and Noiriel have emphasized (this being one of the singular causes of this critical process), the disciplines in themselves were little affected in their institutional delimitations (Bourdieu, 2011; Noiriel, 2005).

Without lingering too long on this already well mapped history, I want to emphasize here how what is understood as the "crisis" of the humanities, in this specific moment of its history, between the 1970s and 1980s, was not due so much to its institutional fragility, but to the transformations which destabilized certain fundamental facts in their condition of emergence. As the disciplines reached a higher degree of autonomy and specialization, allowed by the strengthening and the expansion of the university institution, they promoted a critical movement, called by some "self-reflection", faced with and allowed by the exhaustion of the nineteenth century experiences which characterized their formation. The critique of metanarratives, the linguistic turn, post-colonial criticism, and even the problematization of the political uses of history and memory, profoundly impact on our forms of understanding and the manner in which we prepared our research agendas, but at that moment little affected the institutional stability of disciplines.

As the current forms of national and global identity have connected more to memories than to historical narratives, within the process of "flexible accumulation" of capital and of "space-time compression", as well as when they stopped being fundamentally anchored on the teaching system to compete with the variety of medias available, the discipline of history sees itself constrained to justify its institutional existence like never before, as well as redesigning its mode of social insertion. While it is now of little interest to the historian to serve that old role of pedagogue of the nation, to the extent that greater autonomy of their conditions of production has been won, nevertheless, it is important to say that the 
maintenance of this old and now annoying employee is of much less interest to states, in their current configuration. Not by chance, in the epilogue to the recent Oxford History of Historical Writing, Allan Megill points to this moment of inflection in the discipline of history, marked by the loss of this institutional centrality, to competition with other narratives of memory and the need to surpass the national landmark as a central criterion of production and legitimation (Megill, 2011).

Nevertheless, it is in the wake of this widespread process of acceleration and the growing asynchrony of contemporary social experiences that the institutional place of the discipline of history and its pedagogical roles are placed in question. The traditional repertoire linked to it, formed by an ordination of past societies in periods and narratives, appears to be no longer understood as an appropriate or necessary tool for the demands of the present, or at least of a present which is increasingly spatially expanded by the logical of temporal flexibility of the global market.

\section{Third movement: between the historical past and the practical past}

Given this wide temporal arc which marks the conditions of emergence and the crisis of the discipline of history, I would like to present a brief reflection about recent debates in Brazil, involving the profession of the historian and the preparation of a single national curriculum. The aim here is not to make a detailed and verticalized analysis, linking texts and authors, but rather to perceive the general orientation of the arguments that the category has prepared in this crisis, taking into account its institutional place of enunciation, the National Association of History (Associação Nacional de História - ANPUH), and thus to contribute to a broader reflection on the tensions of the figuration of contemporary disciplinary identity. ${ }^{2}$

The debate about the professionalization of the historian, despite having a long trajectory, is currently centered on a bill going through the Brazilian congress. It is intended to regulate the profession of the historian, defining certain minimum conditions for the university formation necessary for the exerciser of the activity, as well as the need for bodies and institutions to have in their staff, professionals qualified in accordance with the regulations, if they exercise any type of "service in history" (a term from the bill). What this "service in history" actually specifies is not stated, though the term in itself appears to indicate a concern with approximating the profession with contemporary market tendencies, with the "services sector", marked both by the diversification of medias and spaces for the consumption of the past, as by continuous transformations in labor posts; also resulting in the impossibility of determining beforehand in a "bill" what could specific work in "services in history".

${ }^{2}$ All the texts from the ANPUH site were accessed in August 2016. 
On the ANPUH site, by searching for the terms "profession/professionalization", around 55 short texts and reports referring to the bill can be found. All the texts published on the site are affirmative about the professionalization proposal, and there are no publications against the proposal. They exist, but they are circumscribed to the external environment of the association"s site, in debates and polemics in newspapers and social networks. Something distinct from what occurred with the debate about the Basic Curriculum, where different voices and perspectives coexisted and confronted each other intensely on the association"s platform. While there is thus a strong homogeneity in public presentations about the profession of historian, in the debate about the constitution of its forms and pedagogical purposes we found some structural elements of divergences.

In relation to the profession, two central foci of argumentation can be perceived: one aimed at pragmatic needs for regulation, connected to the defense of a labor market for those with degrees in history or with post-graduate degrees in the area; and the other on the definition of values and abilities which qualify this history professional.

In relation to the first point, linked to the defense of a labor market, it is worth highlighting first of all a certain inversion, where the interest in creating positions and places for profession activity for historians no longer comes from the state, as occurred in the formation of the discipline, which has now become a demand "from below", from the group itself, in defending and expanding its fields of activity in a new social scenario. A field of action no longer restricted to teaching and research, but now covering a diversified list of occupations, from archival administrative positions to audiovisual production. In addition, the urgency for the regulation of the profession cannot be considered at the moment without associating it with the stupendous increase, as Jerome de Groot highlighted, of a diffused and varied consumption of history in recent years (Groot, 2009). The recent emergence of fields such as "digital history" and "public history" and the importance which they have gained also point to these transformations (Noiret, 2015).

In relation to the second focus of argumentation, linked to the identity of this historian, what stands out is the preponderant use of determined epistemic virtues inherited from the disciplinary tradition, such as "objectivity" and "distancing", associated with others which we could consider as more contemporary and linked to the new pressures of the university and social context, such as "excellence". These virtues are normally associated in text with "specific abilities" which shape what was synthesized during the debate, in different moments, such as the "perspective of the historian" a mode of perception which singularize it in relation to other modes of dealing with the past. Amongst the most cited are the capacity to read (a "reading knowledge"), allowed both by the dominion of "technical capacities", as well as by virtues such as "perseverance" and "suspicion" in dealing with documents. The old topos of the historian as a reader is (re)updated here, reinforcing the connection of the primary professional identity with the work of documental exegesis. In the texts, what 
tends to be highlighted is the defense of a specific formation of the historian, centered both on technical abilities linked to documents, and in determined epistemic virtues capable of creating objective and true historical knowledge about the past.

It is important to highlight that the choice and the use of these virtues and abilities, taken to a great extent from an image inherited from the disciplinary tradition, were directed to a specific situation and a specific ideal public, other than the historians themselves. Above all, they converge on the persuasion of political agents and determined layers of society of the legitimacy and need to regulate the profession, faced with other non-specialized modes of working with the past - both amateur, without higher level courses, and other professionals, varying from the journalist to the sociologist, or to the archivist. This performatic nature of the discourse directs the use of certain more socially sedimented and accepted images about the identity of the historian, to the detriment of dealing with "hotter" questions which have formed the agenda and the theoretical-methodological debates of the discipline in recent decades.

In the debate about the Common National Basic Curriculum (Base Nacional Comum Curricular - BNCC), which aims to establish the principles which will organize the teaching of history for fundamental education, the scenario and the places of enunciation are distinct and more heterogenous. What has marked this debate, also with around 50 entries on the Association"s site, is a bitter dispute about the purposes of the teaching of history and the narrative forms involved. While there is a certain homogeneity in the texts in relation to the basic aim of teaching, aimed at the formation of citizenship rather than the demands of the market, there is no univocal understanding about how the teaching of history will produce this citizenship.

The relationship between history and citizenship moves between oppositions, including: identity x alterity; national x cosmopolitan; unity x plurality. In turn, these oppositions result in different narrative and chronological matrices, including or excluding different pasts. With this they dispute, for example, how much centrality the history of Brazil should have, how the different social groups should be represented, which values should be linked to them, and finally, what are the most appropriate languages to describe them. What most stands out in this process is the difficulty of accommodating in the same narrative order, such diverse political and historical visions. ${ }^{3}$

In this debate, the connection between history, identity, and nation is still presented as a central point, both of agreement and conflict. Agreement to the extent that the connection is a common assumption in the debate which defines the inherited place of the discipline. History is seen here as essentially linked to forms of national history, passing through the umbilical relationship between citizenship and the Nation-State. The disagreement is about how this relationship should be established today. For example, a criterion in

${ }^{3}$ The recent sequestration of BNCC by the National Congress represented the end of dissensus, being resolved in a heteronomous and equally authoritarian manner. 
which the nation, in its plurality, is the central nexus which connects the teaching of other pasts - the case of the first BNCC proposal - is contrasted with another, in which other pasts, understood in their alterity, serve as ballast to problematize elements of national history - as configured in the second version of the proposal.

Nevertheless, while the nation and the identity function of history still remain as more or less consensual points in the debate - following, in this sense, a more global tendency - , the disagreements and the bitter disputes about how history should be taught, especially the history of Brazil, have revealed a very fragmented scenario of the place and the forms of historical narrative, something which still seems far from being resolved. While, until the middle of the twentieth century, the discipline of history served as a central element of the synchronization of a national memory within universal history, now it seems to find difficulties, at the same time, in meeting the distinct and pressing social demands and accommodating them in the narrative and pedagogical forms inherited from its own tradition. The new content of experience cannot be fitted in without conflicts with the assumed contents of its form. Added to this is the current scenario of contemporary society, as highlighted by Aleida Assmann and Sebastian Conrad, in which this role of the synchronization of memories, in the globalized or transnational space, is processes less by the school discipline of history than by the variety of medias available in the different social groups (Assmann; Conrad, 2015).

While the focus of the first debate is on the technical abilities and epistemic virtues which guarantee the professional historian the controlled production of a historical truth (distancing, skepticism, and objectivity in dealing with documents), in the second debate, the focus is directed at the diffuse consumption of pasts, the demands of memory, and what is now being labelled as the "practical past", aimed at ethical and political dimensions (White, 2014). Aimed at distinct publics and purposes, these two current debates reveal both the permanence of the traditional images of the historian, sedimented by disciplinary inheritance, but also the need for its reorientation in light of contemporary challenges, such as the redefinition of the objects and chronological focuses which define the teaching curriculum, the insertion and formation of new abilities aimed at new labor markets, and working with the demands for memory of different social, ethnic, and gender groups and identities. ${ }^{4}$

\footnotetext{
${ }^{4}$ The tension between a disciplinary past and a practical past is marked, for example, in the speech given by Rodrigo Patto, then president of ANPUH, to the members of the Association, delimiting the distinction between the professional historian and the amateur one: "The distinction lies in the fact that history operates with scientific procedures, follows a method, is based on the critique of sources and the search for diversified evidence. The historian should be skeptical of their sources, should investigate them in search of truth, a target which is unattainable in the pure sense, but which can still present to the public a more critical and reflexive knowledge. We can also satisfy the curiosity and the need for the entertainment of the general public, but with the peculiarity of including the "special treat" in the package, in other words leading the reader to critical reflection", (Patto, 2016).
} 
It can be said that the discipline of history appears nowadays to be moving in a tense manner between a disciplinary past and a practical past. A disciplinary past whose practical reasons are linked to the conditions of survival and reproduction of the discipline and the historian in a university and school system; a practical past constituted by the pressures of a scenario marked by the diffusion and expansion of the means of representation of the past, by the effects of social acceleration, and by the globalization of social and national memories.

Nevertheless, in this broad temporal arc which I have sought to sketch, the greatest conflict which seems to mark the condition of discipline of history, and of the humanities in a general form, can be seen as a confusion between the exhaustion of certain original criteria of the emergence of disciplines and the exhaustion of the disciplinary form in itself. The question which is imposed in this scenario is whether the exhaustion of the criteria for the emergence of disciplines, sedimented since the nineteenth century, should necessarily signify the exhaustion of the disciplinary form in itself, as an institutionally established social sphere, granted relative autonomy for the production of knowledge and languages. In this sense, it is not possible to think of the future of the disciplines in the Humanities without thinking, at the same time, of the defense and the reformulation of a project of the university as a socially constituted autonomous space, in which different protocol languages to describe and think society and social groups can develop in what Habermas has called a continuous "communicative combat" (Habermas, 1993). Work with language and a communicative combat which are theoretically enriched in a manner proportional to the democratization of the university, since social diversity creates the refining of categories based on which society can think about itself.

Reflecting on a possible post-disciplinary era, Jean Louis Fabiani highlights some problems which seem important in this sense. In mapping the debates about the exhaustion of certain disciplinary premises and a possible fusion of disciplines such as history, sociology, and anthropology, he asks if this fusion or reformulation comes from above or below. In other words, if it is a movement produced within disciplinary, university, logic, or a product of external intervention from the state or the market (Fabiani, 2012). Returning to the examples cited at the beginning of this paper, it is possible to understand how the projects for the reform of the school curriculum in different countries, including Brazil, indicate that the latter option is closer to occurring. State agents, knowing that they could not intervene directly in the organization of disciplines, acted on the base of their reproduction - teaching - and their forms of financing, provoking their slow strangulation. In this way, this post-disciplinary age, promoted by bureaucrats and by an administrative discourse, covered a neoliberal nightmare, marked by a fluid world, with provisional configurations. As different studies have demonstrated, there is a strong tendency for the implementation and/or incorporation of distinct forms of universities in different countries, with an auditive and evaluative logic commonly called "New Public Management". It is composed of a type of general grammar based 
on which different spheres become objects of an intervention based on concepts such as "efficiency", "transparency", and "accountability". As Chris Lorenz has highlighted, the typical consequence of this type of process is the emergence of a system of bureaucrats, inspectors, commissioners, and specialists which ends up eroding the autonomy of disciplines (Lorenz, 2012). Normally translated into quantitative assessment benchmarks, associated with productivity, the auditive logic implies the imposition of a general and abstract logic, which does not converge with the specifities and the meanings of the functioning of the activities measured, creating the deformation of these activities and the corruption of what they would like the guiding concepts to have originally meant. While the production numbers in the area are eloquent in showing vigor, they reveal little about their real effects. In a study focused on the field of letters, for example, Jaime Ginzburg showed the gap between the valorization of publication in the periodicals assessed as Al by Capes and the use in citations and debates of the same periodicals. Of the 85 articles analyzed, only three citations were found (Ginzburg, 2015, p. 25; Araujo, 2017). One of the effects of this process is thus the sterile proliferation of articles (or collections) without readers, whose effects in debates are increasingly hard to note. In addition, this logic implies to the great extent the incorporation by some academics of the same language, affecting how they seen and evaluate themselves. In this sense, Chris Shore indicated how this auditive culture affects the way researchers and professors perceive themselves: "it encourages them to measure themselves and their personal qualities against the external 'benchmarks', 'performance indicators' and 'ratings' used by the auditing process" (Shore, 2008, p. 281).

In this context, disciplines appear to be facing two options: either try to legitimate themselves faced with these new demands and languages which have been imposing themselves from outside with an incredible vigor and velocity (and in this way prove their instrumental "utility", demarcating spaces where they can "render services"), or seek their legitimation within the principles of the autonomy within the university community and, with this, defend this autonomy as a principle and condition for the production of knowledge. In the attack which we have experienced in relation to the humanities, in particular, and the university as a whole, the greatest risk we face is to internally erode the conceptual bases which (still) sustain them. By applying vocabulary such as "excellence", "efficiency", and their quantitative measures to the establishment of rankings, for example, we end up vampirizing all the daily practices of the university, and with this radically and silently change its structure in the medium term. Defending the university, as well as the humanities themselves, is not to try to legitimate them through a language which apparently will cause the persuasion effects already hegemonically placed in certain social spheres, such as the economy, but rather to take advantage of the lexicon which belongs to them. As Stefan Collini recently noted: 
the use of 'excellence' and similar bits of patter does have a function: it signals that the university accepts the sovereignty of the current cant, especially the domination of audit populism. [...] And it not only signals acceptance of the coercive fiction of competition - we try to excel, to beat the others, to win — but, implicitly, it also signals acceptance of the conventional forms of the measurement of achievement. This is the great unspoken about 'excellence': since it is entirely devoid of content in itself, its presence can only be vouchsafed by some quantitative evidence recognized by outsiders (Collini, 2017, p. 43)

Defending the university implies, ultimately, through languages which belong to them, also defending another idea of society. In a context of the fragmentation of the public sphere, perhaps it is also worth thinking of the university as a possible place for the preparation and expansion of languages and, thus, as an element which is a component of the public sphere, no longer the figure of the solitary intellectual, but as a center which channels various social demands and groups. The democratization of the university thus becomes not only a desirable ethical and political element, but also something that composes the actual theoretical legitimation of the humanities, since it is democratization which will finally generate, through disciplinary autonomy and the communicative combat, the complexification of the languages for the description of the world through which society, and consequently the humanities themselves, can be thought of beyond their immediate present, opening them to a future not given in advance. Even though there is a certain institutional inertia in disciplines and even though their corporatism imposes a temporality in which changes do not suddenly happen, accepting them at any cost from specific external interference can signify the choice of the end of what is most fundamental in the university and space and the disciplinary form: the possibility of opening for what is not given in advance. Including the opening for the preparation of new and unpredictable languages, even more in a world so lacking in the imagination of futures. However, for this, it is necessary not only to confront what comes from outside the disciplinary tradition, but the tradition itself. After all, as Humboldt stated: "[University] autonomy is threatened not only by the state, but also by the actual [university] institutions when, in assuming a determined orientation, they impede the orientation of any other" (Humbold, 2003, p. 87). 


\section{Bibliographic References}

ABBOTT, Andrew. Chaos of disciplines. Chicago: Chicago University Press, 2001.

ARAUJO, Valdei Lopes de. O regime de autonomia avaliativo no Sistema Nacional de Pós-Graduação e o futuro das relações entre historiografia, ensino e experiência histórica. Anos 90 (Porto Alegre). v. 23, n. $44,2017$.

ASSMANN, Aleida. Construction de la memóire nationale: une brève histoire de l'idée allemand de Bildung. Paris: Éditions de la Maison des sciences de l"Homme, 1994.

; CONRAD, Sebastian (Ed.). Introduction. In: Memory in a global age: discourses, practices and trajectories. New York: Palgrave, 2010.

BERGER, Stefan. The power of national pasts: writing national history in nineteenth-and twentieth-century Europe. In: BERGER, Stefan (Ed.). Writing the nation: a global perspective. New York: Palgrave, 2007.

BOURDIEU, Pierre. Homo academicus. Florianópolis: Editora da UFSC, 2011.

COLLINI, Stefan. Speaking of universities. London: Verso, 2017.

DARDOT, Pierre; LAVAL, Christian. A nova razão do mundo: ensaio sobre a sociedade neoliberal. São Paulo: Boitempo, 2016.

DILTHEY, Wilhelm. Vivência e autobiografia. In: Filosofia e educação. São Paulo: Edusp, 2010.

DUCHET, Michele. Le partage des savoirs : discours historique, discours ethnologique. Paris: La Découverte, 1985.

ELLIOT, Anthony; URRY, John. Mobile lives. London: Routledge, 2010

ESTADÃO, Educarpara afelicidade, de 9/9/2015. Available at: http://vida-estilo.estadao.com.br/blogs/educarpara-a-felicidade/educar-filhos-sem-ter-planos-de acao-e-tatear-no-escuro/. Accessed on: 10 abr. 2016.

ESTADÃO, Profissões do futuro: historiadores corporativo, de 25/7/2015. Available at: http://educacao.estadao.com. br/noticias/geral,profissoes-do-futuro-historiadorescorporativos, 1730012. Accessed on: 10 abr. 2016.

FABIANI, Jean-Louis. Du chaos des discipline à la fin de l"ordre disciplinaire?, Pratiques, p. 153-154, 2012.

GENGNAGEL, Vicent; HAMANN, Julian. The making and persisting of modern German humanities: balancing acts between autonomy and social relevance. In: BOD,
Rens; MAAT, Jaap; WESTSTEIJN, Thijs (Eds.). The making of humanities. Vol. III. The Modern Humanities. Amsterdan: Amsterdan University Press, 2015.

GINZBURG, Jaime. Periódicos acadêmicos: antagonismo entre produção e leitura, Expedições: teoria da história e historiografia, vol. 5, n. 1, p. 10-41, julho, 2014.

GRAFTON, Anthony. As origens trágicas da erudição: pequeno tratado sobre as notas de rodapé. Campinas: Papirus, 1998.

GROOT, Jerome de. Consuming history: historians and heritage in contemporary popular culture. London and New York: Routledge, 2009.

HABERMAS, Jurgen. A ideia da universidade: processos de aprendizagem, Revista brasileira de estudos pedagógicos, v.74, n. 176, p. 111-130, 1993.

HARTOG, François. O século XIX e a história: o caso Fustel de Coulanges. Rio de Janeiro: Editora da UFRJ, 2003.

HARVEY, David. A condição pós-moderna. São Paulo: Loyola, 1997.

HASSAN, Robert. Empires of speed: time and acceleration of politics and society. Leiden: Brill, 2009.

HEMON,Aleksandar. O livro das minhas vidas. São Paulo: Rocco, 2013.

HUMBOLDT, Wilhelm. Sobre a organização interna e externa das instituições científicas superiores em Berlim. In: KRETSCHMER, Johannes; ROCHA, João Cezar de Castro (Orgs). Um mundo sem universidades? Rio de Janeiro: Eduerj, 2003.

JASPERS, Karl. Ciência e verdade, O que nos fazpensar, n. 1, p. 104-117, 1989

KOSELLECK, Reinhart. Sobre a indigência teórica da ciência da História. In: Estratos do tempo: estudos sobre história. Rio de Janeiro: Contraponto/PUC-Rio, 2014.

LÉON, Pablo; MARTÍN, Jesus Izquierdo (Eds.). El fin de los historiadores: pensar históricamente en el siglo XXI. Madrid: Siglo XXI, 2008.

LORENZ, Chris; BEVERNAGE, Berber. Negotiating the borders between present, past and future. In: Breaking up time.: negotiating the borders between present, past and future. Göttingen: Vandenhoeck \& Ruprecht, 2013. LORENZ, Chris. If you"re so smart, why are you under surveillance? Universities, neoliberalism, and 
new public management, Critical Inquiry, 38, p. 599629,2012

MEGILL, Allan. Epilogue: on the current state and future state of historical writing. In: The Oxford History of Historical Writing, Vol. 5. Oxford: Oxford University Press, 2011.

NOIRET, Serge. História Pública Digital, Liinc em Revista, Rio de Janeiro, v. 1l, n. 1, p. 28-51, 2015.

NOIRIEL, Gérard. Sur la "crise" de l"histoire. Paris: Gallimard, 2005.

NUSSBAUM, Martha. Sem fins lucrativos: por que a democracia precisa das humanidades. São Paulo: Martins Fontes, 2015

ORDINE, Nuccio. A utilidade do inútil. São Paulo: Zahar, 2016.

PASSERON, Jean Claude. O raciocínio sociológico. São Paulo: Vozes, 1995.

PATTO, Rodrigo. Os lugares dos historiadores na sociedade brasileira, Conferência de abertura do XXVIII Simpósio Nacional de História, Florianópolis, História da historiografia, Ouro Preto, 22 dez. 2016.

PEREIRA, Mateus; ARAUJO, Valdei Lopes de. Reconfigurações do tempo histórico: presentismo, atualismo e solidão na modernidade digital, RevistaUFMG, Belo Horizonte, v. 23, n. 1 e 2, 2016

PIGLIA, Ricardo. Los diarios de Emilio Renzi. Los años felices. Barcelona: Anagrama, 2016.
RANCIÈRE, Jacques. Os nomes da história: um ensaio de poética do saber. São Paulo: Pontes, 1994.

RICOEUR, Paul. A memória, a história, o esquecimento. São Paulo: Campinas, 2010.

ROSA, Hartmut. Accélération: une critique sociale du temps. Paris: La Découverte, 2010.

ROSA, Hartmut; SCHEUERMAN, William E. (Ed.). High-speed society: social acceleration, power and modernity. Philadelphia: Pennsylvania University Press, 2009.

ROSANVALLON, Pierre. Le moment Guizot. Paris: Gallimard, 1985.

SHORE, Chris. Audit culture and illiberal governance: universities and the politics of accountability, Anthropological theory, vol. 8, n. 3, p. 278, 2008.

TOLEDO, Maria Aparecida Leopoldino Tursi. A disciplina de história no império brasileiro, Revista HISTEDBR On-line, Campinas, n. 17, p. 1-10, mar. 2005.

TURIN, Rodrigo. História da historiografia e memória disciplinar: notas para um debate, História da Historiografia, Ouro Preto, n. 13, dez. 2013.

WEBER, Max. Ciência como vocação. In: Ciência e política: duas vocações. São Paulo, Cultrix, s/d.

WEINGART, Peter. A short history of knowledge formations. In: FRODEMAN, Robert (Ed.). The Oxford Handbook of Interdisciplinarity. New York: Oxford University Press, 2010.

WHITE, Hayden. The practical past. Evanston: Northwestern University Press, 2014. 